\title{
SPECIFICITIES OF LATVIAN PRE-SCHOOL CHILDREN'S GROWTH
}

\author{
Silvija Umbraško, Ilva Dul,evska, Anita Oginska, \\ Ruta Žagare, Roberts Veidemanis \\ Department of Anatomy and Anthropology, Riga Stradinš University, Latvia
}

\begin{abstract}
This study was carried out within the pilot project ordered by the Ministry of Education for the government to decide if the children should start school from the age of 6 or 7 years. The study results prove that the physical development of children at this age is greatly variable, the dispersion in all the parameters is very great. Thus, we can conclude that one should decide of starting school at the age of 6 years individually by the child's parents jointly with the family doctor. On average the physical development parameters correspond to the norm, though a part of children are lagging behind their peers. The growth and development at the age of six and seven years is different and individual, there is no pronounced gender dimorphism.
\end{abstract}

Keywords: physical developmet, growth, specificities

\section{INTRODUCTION}

The concluding age of the first childhood period is 6 and 7 years. At this age the first increased growth period ends, the dental changes occur on average from the age of 6 years. In six-year-olds different growth changes are observed in the cranial bones, the sinuses increase, the nasal cavity grows, more intensive is the growth of spinal vertebrae in width and height. Up to 6 years there are poorly developed muscle tendons, ligaments, fasciae [1]. At the age of 6 and 7 years the spine is particularly sensitive, there develops the spinal neck lordosis. The trunk muscles are more poorly developed rather than extremity muscles, they 
get tired much faster under a prolonged uniform statistical load. At this age the nervous system is labile, the delay processes develop, the children become more coordinated.

\section{THE AIM}

To study and assess the growth specificities in six-and seven-year-old children.

\section{MATERIAL AND METHODS}

There were screened 84 six-year-old and 188 seven-year-old children in 27 educational institutions in various Latvian regions and in Riga pre-school educational institutions (PII), whose parents have given their written consent. Many parents participated at the moment of measurements. Measurements were done by R. Martin's and K. Saller's (1957-1966) methods [8]. Certified instruments were used. Posture parameters were determined by G. Makarova's (2003) method [7]. Feet plantography was done by I. Aulik's (1983) method [2]. Plantogrammes were processed graphically and mathematically, the longitudinal and transversal arches were analyzed. The physical developmental parameters were detected - the height $(\mathrm{cm})$, the body mass $(\mathrm{kg})$, the circumference of the head, chest, waist, hips ( $\mathrm{cm}$ ), vital lung capacity (VC), (ml), the systolic and the diastolic blood pressure ( $\mathrm{mm} \mathrm{Hg}$ ), pulse (times/minute), etc. parameters. The obtained data are analyzed by the SPSS, MS Excel computer programmes.

\section{RESULTS AND DISCUSSION}

The growth and development process occurs unevenly and for each age there are characteristic anatomically physiological specificities. The growth is characterized by the increase of the height and the body mass. The rate of their changes points to the most significant stages in the growth and development process. The rate of boys' and girls' growth up to the onset of puberty does not greatly differ. In Table 1 we can see the average, minimum and maximum height of the children under study. 
Table 1. Children's growth length

\begin{tabular}{clcccc}
\hline \multirow{2}{*}{$\begin{array}{l}\text { Nr. } \\
\text { p.k. }\end{array}$} & Stature/height $(\mathbf{c m})$ & \multicolumn{2}{c}{$\mathbf{6}-$ year-olds } & \multicolumn{2}{c}{$\mathbf{7}$-year-olds } \\
\cline { 3 - 6 } & & $\begin{array}{c}\text { boys } \\
\mathbf{N}-\mathbf{4 5})\end{array}$ & $\begin{array}{c}\text { girls } \\
(\mathbf{N}-\mathbf{3 9})\end{array}$ & $\begin{array}{c}\text { boys } \\
(\mathbf{N}-\mathbf{9 9})\end{array}$ & $\begin{array}{c}\text { girls } \\
\mathbf{( N - 8 9 )}\end{array}$ \\
\hline 1. & Average height $(\mathrm{cm})$ & $119.6 \pm 5.1$ & $119.1 \pm 6.3$ & $122.8 \pm 5.4$ & $122.2 \pm 5.5$ \\
\hline 2. & Minimum height & 106.4 & 97.5 & 108.1 & 109.3 \\
\hline 3. & Maximum height & 130.8 & 128.5 & 138.3 & 137.0 \\
\hline 4. & Difference of height & 24.4 & 31.0 & 30.2 & 27.7 \\
\hline
\end{tabular}

In the study of K. Segleniece and R. Millere (1962-1963) the average height of six-year-old boys was $116.3 \pm 4.8 \mathrm{~cm}$, (min. -101.5 , max. $-127.4 \mathrm{~cm})$. The difference between the minimum height of six-year-old boys and the maximum one in the study of these authors was also great $-25.9 \mathrm{~cm}$. The parameters of the height from 6 to 7 years of age within 50 years is $+2.5 \mathrm{~cm}$. In the study of R. Millere the average height of 6-year-old girls was $115.3 \pm 4.9 \mathrm{~cm}$, (min. $-101.5 \mathrm{~cm}$, max. $-131.4 \mathrm{~cm}$ ), the difference $29.9 \mathrm{~cm}$. The increase of the average height of six-year-old girls within 50 years has increased by $2.6 \mathrm{~cm}$ [9]. In our study from the longitudinal parameters we have also measured the length of the spine $(\mathrm{cm})$. For six-year-old boys the mean value of the spine length is $45.3 \pm 2.6$, ( $\min .-39.0 \mathrm{~cm}$, max. $-51.5 \mathrm{~cm}$ ), for girls the mean value is $44.7 \pm 3.2$, (min. $-35.0 \mathrm{~cm}$, $\max .-51.0 \mathrm{~cm}$ ). At the age of 7 years the boys' spine is on average $46.1 \pm 2.7 \mathrm{~cm}$ long $(\mathrm{min} .-40.0 \mathrm{~cm}$, max. $-53.0 \mathrm{~cm}$ ), for girls - on average $-46.1 \pm 3.1 \mathrm{~cm}(\min .-39.0 \mathrm{~cm}$, max. $-55.0 \mathrm{~cm})$. The increase of the mean value of the spine length from 6 to 7 years in boys is $0.8 \mathrm{~cm}$, in girls $-1.4 \mathrm{~cm}$. Thus, the girls' height within a year on average increases faster than the boys' at the same age due to the faster spinal growth rate. Assimilation and dissimilation are closely related processes, however, they are not always mutually balanced. During the growth period both processes proceed very intensively, though assimilation prevails over dissimilation. This is the reason why the body mass during this period intensively increases [3, 10]. During the growth period metabolic and energy reactions should provide not only the body's existence and rejuvenescence, but the growth and development as well, therefore during this period the metabolism in the body bears an extra load and undergoes essential specificities [3]. The children's body mass and total measures (somatotype) affect the quality of their motor capacity for work [6].

In our study the body mass of six-year-old children was variable. The mean values of the body mass, minimum and maximum body mass, are depicted in Table 2. 
Table 2. Children's body mass parameters

\begin{tabular}{|c|c|c|c|c|c|}
\hline \multirow{2}{*}{ Nr. } & \multirow{2}{*}{ Height (cm) } & \multicolumn{2}{|c|}{6 -year-olds } & \multicolumn{2}{|c|}{7 - year-olds } \\
\hline & & boys & girls & boys & girls \\
\hline 1. & Average body mass & $22.5 \pm 4.5$ & $22.1 \pm 3.8$ & $24.0 \pm 3.7$ & $23.9 \pm 3.8$ \\
\hline & Minimum body mass & 16.5 & 14.0 & 15.9 & 16.9 \\
\hline & Maximum body mass & 42.0 & 32.3 & 40.0 & 42.3 \\
\hline & $\begin{array}{l}\text { Difference between minimum } \\
\text { and maximum body mass }\end{array}$ & 25.5 & 18.3 & 24.1 & 25.4 \\
\hline
\end{tabular}

In one age group both for boys and girls there are a very great differences in the body mass. The mean increase of the mass value per year is slight in boys $1.5 \mathrm{~kg}$, in girls $-1.8 \mathrm{~kg}$. Comparing the average results of our study with those of K. Segleniece and R. Millere (1962-1963), within 50 years the body mass in 6-year-old boys has increased by $0.7 \mathrm{~kg}$, 6-year-old girls - by $0.76 \mathrm{~kg}$. Within the period of 50 years the mean value of the body mass at this age has changed little. The child's body, similarly to that of adults, has a very great variability as to the height and the body mass [6]. Thus, children, within one age, grow and develop differently and individually.Scientists have found that at present there is a tendency in the world for children's overweight, one fourth of the whole world's children are obese. The main reason is considered to be passive lifestyle and wrong nutrition. Children with overweight are in danger of a series of illnesses - hypertension, hyperlipidaemia, II type diabetes, dysfunction of growth hormon, respiratory and orthopaedic diseases. Self-confidence and socialization are usually limited. $40 \%$ of overweight children are considered to be overweight also at an adult age $[6,11]$. In our study only 12 children $(4.3 \%)$ are overweight and I degree obesity. The children in the study were determined also for the circumference of the head, chest, waist, hips. The head circumference in 6-year-old boys is on average $52.9 \pm 4.6 \mathrm{~cm}$, in 7-year-olds $-52.9 \pm$ $1.5 \mathrm{~cm}$. There is no average yearly increase, but individual variations are great. The girls' head circumference at the age of 6 years on average is $51.7 \pm 1.5 \mathrm{~cm}$, at the age of 7 years $-51.9 \pm 1.3 \mathrm{~cm}$. There is no average increase during the year. The chest circumference for 6-year-old boys on average is $57.9 \pm 8.2 \mathrm{~cm}$, for 7-year-olds $-59.9 \pm 3.7 \mathrm{~cm}$, the yearly increase $2.0 \mathrm{~cm}$, individual variations are great; for 6-year-old girls $57.2 \pm 3.6 \mathrm{~cm}$, for 7-year-olds $-58.7 \pm 4.3 \mathrm{~cm}$, the yearly increase $1.5 \mathrm{~cm}$. The waist circumference for 6-year-old boys on average $53.8 \pm 7.6 \mathrm{~cm}$, for 7-year-olds $-55.0 \pm 3.6 \mathrm{~cm}$, the yearly increase $1.2 \mathrm{~cm}$, the 
girls at the age of 6 years on average also $53.8 \pm 4.6 \mathrm{~cm}$, at the age of 7-years $-54.0 \pm 4.1 \mathrm{~cm}$, the yearly increase very slight $-0.2 \mathrm{~cm}$. Children's physical fitness is in close relation to the child's growth and development processes [4]. Physical fitness is used in order to state the adolescents' health. Fitness in Europe, as well as in Latvia, is most commonly estimated by the EUROFIT test [5]. Fitness depends also on a child's cardiovascular, respiratory and neuromuscular systems' individual development level [1]. For the first time in Latvia the children under study were measured for the vital capacity of lungs (VC), the systolic and the diastolic arterial blood pressure, pulse rate and forearm muscle (flexor) strength. The vital capacity of lung volume for 6-year-old boys on average is $1,026.7 \pm 275.8 \mathrm{ml}$, for 7 -year-olds-1,168.7 $\pm 283.1 \mathrm{ml}$, the yearly increase is slight - $142.0 \mathrm{ml}$; for 6-year-old girls $1,069.2 \pm 268.7 \mathrm{ml}$, for 7-yearolds $-1,087.6 \pm 233.5 \mathrm{ml}$, the yearly increase $18.4 \mathrm{ml}$. Individual variations are great. At this age also the chest circumference increase is slight. In the literature the vital lung capacity volume at the age of 5-6 years on average is $1,400 \mathrm{ml}$, it intensively increases after the age of 9-10 years. In puberty VC for boys is higher than in girls [1]. Arterial blood pressure for 6-year-old boys on average is 100.0/69.6 mm Hg, for 7-year-olds $99.9 / 70.4 \mathrm{~mm} \mathrm{Hg}$; for 6-year-old girls 93.4/66.8 mm Hg, for 7-year-olds - 99.0/70.0 mm Hg. Pulse - for 6-year-old boys on average is 75.4 times per minute, for 7 -year-olds -77.5 times per minute; for 6-year-old girls - 66.8 times per minute, for 7-year-olds on average 70.0 times per minute. According to the literature data of the physiological norm for the blood pressure at this age is $99 / 64 \mathrm{~mm} \mathrm{Hg}$, heart rate (pulse) - 95 times per minute [1]. Individual variations for these parameters are very great (pulse between minimum and maximum - 40 times per minute). These data show that at the age of 6 and 7 years the children have a very labile nervous system, which under a slight stress affects the activity of the heart and vascular system. The measurement procedure for many children was like a stress irritator,which increased the blood pressure and pulse. In such children the repeated measurements were done after some time. The similar study is carried out in Riga on assessing children's physical development and fitness starting from the age of 4 years, and we have planned to screen more than 1000 pre-school children, in order to develop standards. 


\section{CONCLUSIONS}

1. The growth and development at the age of 6 and 7 years is different and individual.

2. The increase in height and the body mass within a year is slight, but peers' growth in height is different, parameter dispersion is great.

3. In the children under study an increased growth period at the age of 6 years was not observed, there is no pronounced gender dimorphism.

4. As to starting school at the age of 6 years the issue has to be decided individually by the child's parents jointly with the family doctor.

\section{LIST OF LITERATURE}

1. Aberberga-Augškalne L., Koroḷova O. (2007). Fiziologija ārstiem, Medicinas apgāds, Rīga, 433-478.

2. Auliks I. (1983). Sporta medicīna, Zvaigzne, Rìga, 51-53.

3. Brēmanis E. (2008). Bērnu un pusaudžu trenera rokasgrāmata. Latvijas treneru tālāk izglítības centrs, Rīga, 54-60, 90-93.

4. Jansone R., Krauksts V. (2005). Sporta izglïitibas didaktika skolā. Raka, Rīga, 21-35.

5. Kalniña L., Sauka M., Priedīte I., u.c. (2011). Physical Fitness Reference in Young Latvian Athletes. LU raksti, Rìga, 773, 144-159.

6. Krauksts V. (2006). Bērnu un pusaudžu fiziskās aktivitātes un sports. Drukātava, Riga, 26-27, 34-37.

7. Makarova G. (2003). Спортивная медицина, 108-130.

8. Martin R., Saller K. (1957-1966). Lehrbuch der Anthropologie II , Stuttgart, Fischer Verlag, 661.

9. Segleniece K., Millere R. (1963). Rīgas pilsētas skolēnu fiziskās attīstības standarti. Metodiskie norādijumi, Rīga, 31.

10. Valneris A. (2007). Cilvēka fiziologija. Apgāds Zvaigznes ABC, Rīga, 98, 208.

11. Valika B., Pudule I., Grīnberga D. (2010). Bērnu antropometrisko paradumu un skolas vides pētijums Latvijā, www.vec.gov.lv

\section{Address for correspondence:}

Silvija Umbraško, $\mathrm{PhD}$

Riga Stradiņš University

Institute of Anatomy and Anthropolagy

Kronvalda 9, Riga, LV-1010, Latvia

E-mail: silvija_umbrasko@inbox.lv 